\title{
MOLECULAR WEIGHT DISTRIBUTION OF THE ACRYLONITRILE-VINYL ACETATE COPOLYMER PREPARED BY REDOX POLYMERIZATION ${ }^{* 1}$
}

\author{
By Seiichi Ito ${ }^{* 2 * 4}$ and Chiharu Okada*3*5 \\ ( 2 Otake Plant and * 3 Central Research Laboratory, Mitsubishi Rayon Co., \\ Ltd. 20-1, Miyuki cho, Otake, 739-06 Japan)
}

\begin{abstract}
The molecular weight distributions were estimated for the acrylonitrile-vinyl acetate copolymers (93:7 in weight), which were prepared by continuous polymerization in aqueous medium with the persulfate-bisulfite-ion redox system under the conditions of water/monomer ratio varied in the range from 4 to 1.75 in weight.

The molecular weight distributions were evaluated by $\bar{M}_{\mathrm{v}} / \bar{M}_{\mathrm{n}}$ ratios estimated from viscosity and osmotic measurements, and by $\bar{M}_{\mathrm{w}} / \bar{M}_{\mathrm{n}}$ ratios estimated from gel permeation chromatography. The molecular weight distributions of these polymers were so broad that $\bar{M}_{\mathrm{w}} / \bar{M}_{\mathrm{n}}$ ratio varied between 4 and 6 . No marked difference was observed in the molecular weight distribution of the polymers prepared under the conditions mentioned above.
\end{abstract}

\section{INTRODUCTION}

The continuous polymerization in aqueous medium using the persulfate-bisulfite-ion redox initiation system is important in production of acrylonitrile (AN) polymers. Studies ${ }^{1-4)}$ on the polymerization system with low water/monomer ratios have been reported previously, but studies on the effect of water/monomer ratio on the polymer properties and polymerization behaviors do not seem to be sufficient. The authors studied $^{\text {s) }}$ the properties of polymer slurry and the structures of polymer particles of AN-vinyl acetate (VAc) copolymers (93:7 in weight) which were prepared in the range of water/monomer ratio from 1.5 to 4.0 . We have observed that the structure of the polymer particle became more

"1 Studies on Continuous Polymerization of Acrylonitrile in Aqueous Medium under the Condition of Low Water/Monomer Ratio (Part 7)

${ }^{-4}$ Present address: Fiber Production Development Department, Mitsubishi Rayon Co., Ltd., 3-19, Kyobashi 2 chome, Chuo-ku, 104 Japan

-5 Present address: Wakayama Research Laboratories, Kao Corp., 1334, Minato, Wakayama-shi, 640 Japan compact with decreasing water/monomer ratio, resulting in reduced water contents of dewatered cakes at filtration of the polymer slurry and increased bulk densities of the polymer. It is the main object of this report to reveal the influence of these differences in the polymer particles on the molecular weight distribution (M.W.D.).

\section{EXPERIMENTAL}

\subsection{Materials}

Commercial grade AN and VAc were used for polymerization. Deionized water was used. Commercially available reagents were used without further purification. First grade potassium persulfate (KPS) and sodium hydrogen carbonate $\left(\mathrm{NaHCO}_{3}\right)$ were used as an initiator and buffer, respectively. Special grade sulfur dioxide $\left(\mathrm{SO}_{2}\right)$ was used as a bisulfite ion source and ferrous sulfate $\left(\mathrm{FeSO}_{4}\right)$ as a promoter. Special grade sodium thiocyanate (NaSCN) and distilled $\mathrm{N}, \mathrm{N}$ dimethyl formamide (DMF) were used for the measurements of polymer solution properties.

\subsection{Polymerization Procedures}

A reaction vessel having a capacity of $83 l$ of complete mixing type was charged with water 
adjusted to $\mathrm{pH} 3.0$ with sulfuric acid and it was heated under nitrogen. Feed of monomers and aqueous solutions of $\mathrm{KPS}, \mathrm{SO}_{2}, \mathrm{NaHCO}_{3}$ and $\mathrm{FeSO}_{4}$ was started at a given temperature. The time from start of feed to beginning of overflow from the reactor was adjusted to a given dwell time with the amount of water charged initially, The running time of the polymerization was about 24 hours except for 8 hours of expt. No. 7. The slurries of polymer were taken as samples for evaluation after about 15 hours from start up of polymerization except for about 6 hours in case of expt. No. 7. After the polymerization was stopped by inhibitor solution, the slurry was filtered and washed. The dry polymer sample was obtained by drying the filtered cake at $85^{\circ} \mathrm{C}$ for $90 \mathrm{~min}$. To evaluate the dewatering property of the slurry of polymers, the water content of the cake thus obtained being measured by using a leaf tester at the filtration vacuum of $200 \mathrm{mmHg}$ and at the depth of the cake of $1.0 \mathrm{~cm}$.

\subsection{Viscometry}

Specific viscosity $\left(n_{\mathrm{sp}}\right)$ was measured at $30^{\circ} \mathrm{C}$ in DMF or in DMF containing $0.1 \mathrm{M} \mathrm{NaSCN}(0.1 \mathrm{M}$ $\mathrm{NaSCN}$ /DMF) with a Ubbelohde type viscometer.

Intrinsic viscosity $[\eta]$ was obtained as $\eta_{\mathrm{sp}} / C$ extrapolated to $C=0$ according to eq. (1)

$$
\eta_{\mathrm{sp}} / C=[\eta]+k^{\prime}[\eta]^{2} \mathrm{C}
$$

where $C$ is polymer concentration, $\eta_{\text {sp }}$ specific viscosity and $k^{\prime}$ the Huggins' constant.

\subsection{Osmometry}

Osmotic pressure $(\pi)$ of polymer solution was measured in the range of concentration $(C)$ from 0.1 to $0.5 \mathrm{~g} / \mathrm{dl}$ in DMF at $30^{\circ} \mathrm{C}$ with Mechrolab High Speed Membrane Osmometer Model 501.

Number average molecular weight $\left(\bar{M}_{n}\right)$ was abtained as $\pi / C$ extrapolated to $C=0$ according to eq. (2). The second virial coefficient $\left(A_{2}\right)$ was also obtained by eq. (2)

$$
\frac{\pi}{C}=R T\left(\frac{1}{\bar{M}_{\mathrm{n}}}+A_{2} C\right)
$$

where $R$ is gas constant.

\subsection{Gel Permeation Chromatography (GPC)}

Two kinds of systems were used for GPC measurement. One was a conventional type, Water Associates Model 200 with the column system (G 4000S + G 5000S + G 6000S + G 7000S: each column length, 4 feet; made by Toyo Soda Manu- facturing Co., Ltd.). GPC measurement was performed in $0.1 \mathrm{M} \mathrm{NaSCN} / \mathrm{DMF}$ at $30^{\circ} \mathrm{C}$ : polymer solution injected, $0.3 \mathrm{~g} / \mathrm{dl} \times 2 \mathrm{ml}$; flow rate, $1 \mathrm{ml} /$ min. The other system was a GPC of high speed type constructed by our Research Laboratory with a constant feed pump (Milton Roy Co.), an injector (Waters Associates Inc.) and differential refractometer (Waters Associates Inc.). Another measurement was performed with the column system $\left(\mathrm{GMiX}_{6}+\mathrm{GMiX}_{6}\right.$ : each column length, 2 feet; made by Toyo Soda Manufacturing Co., Ltd.) in $0.1 \mathrm{M} \mathrm{NaSCN} / \mathrm{DMF}$ at $30^{\circ} \mathrm{C}$ : polymer solution injected, $0.2 \mathrm{~g} / \mathrm{dl} \times 0.5 \mathrm{ml}$; flow rate, $2.2 \mathrm{ml} / \mathrm{min}$.

M.W.D. of sample from No. 1 to No. 4 was measured by the conventional type GPC and that of sample from No. 4 to No. 7 by high speed type GPC.

\section{RESULTS AND DISCUSSION}

Polymerization conditions under various water/ monomer ratios and some properties of the polymers are summarized in Table 1 . As previously described ${ }^{5)}$, with decreasing water/monomer ratios in polymerization, the polymer particles became more compact, so that bulk densities of polymers increased and water contents of dewatered cakes decreased.

\subsection{Intrinsic Viscosity and $\bar{M}_{\mathrm{n}}$}

In Fig. 1 and Fig. 2, plots of $\eta_{\mathrm{sp}} / C$ vs. $C$ in $0.1 \mathrm{M} \mathrm{NaSCN} / \mathrm{DMF}$ and $\pi / C$ vs. $C$ in DMF for No. 1 -No. 4 samples are shown. In all cases linear relations were obtained, and values of $\eta_{\mathrm{sp}} / C$ or $\pi / C$ were easily extrapolated to $C=0$. Intrinsic viscosity, Huggins' constant, $\bar{M}_{\mathrm{n}}$ and the second virial coefficient are shown in Table $2 . \bar{M}_{\mathrm{v}}$ in Table 2 were obtained by equation ( 4 ) described later. Heterogeneity index, $\bar{M}_{\mathrm{v}} / \bar{M}_{\mathrm{n}}$ ratio, was used in place of $\bar{M}_{\mathrm{w}} / \bar{M}_{\mathrm{n}}$, since $\bar{M}_{\mathrm{w}}$ was not obtained by direct measurement. $\bar{M}_{\mathrm{v}} / \bar{M}_{\mathrm{n}}$ ratios for No. $1-$ No. 4 samples were roughly 6 and no marked difference was observed in $\bar{M}_{\mathrm{v}} / \bar{M}_{\mathrm{n}}$ ratio of polymers prepared under the condition of water/ monomer ratio varied from 4.0 to 2.5 .

\subsection{Evaluation of M.W.D. from GPC}

Masuzawa et al. ${ }^{6-8)}$ have already studied on M.W.D. of polyacrylonitrile (PAN) by GPC. They have shown ${ }^{7)}$ that M.W.D. of PAN prepared by redox system could not be properly evaluated by GPC measurement in DMF, because M.W.D. show 
Table 1 Polymerization conditions ${ }^{a}$ with various water/monomer ratios and some properties of polymers

\begin{tabular}{|c|c|c|c|c|c|c|c|}
\hline Expt. Na. & $\begin{array}{c}\text { Water } \\
\text { Imonomer } \\
\end{array}$ & $\mathrm{SO}_{2} / \mathrm{KPS}$ & Temperature & Dwell time & $\begin{array}{l}\text { Agitation } \\
\text { speed }\end{array}$ & $\begin{array}{l}\text { Bulk density } \\
\text { of polymer } \\
\end{array}$ & $\begin{array}{l}\text { Water content } \\
\text { of the cake }\end{array}$ \\
\hline & (wt ratio) & (mol ratio) & $\left({ }^{\circ} \mathrm{C}\right)$ & $(\min )$ & $(\mathrm{rpm})$ & $\left(\mathrm{g} / \mathrm{cm}^{3}\right)$ & (\% dry basis) \\
\hline 1 & 4.0 & 10 & 50 & 60 & 214 & 0.26 & 183 \\
\hline 2 & 3.2 & 10 & 50 & 60 & 260 & 0.34 & \\
\hline 3 & 2.5 & 10 & 50 & 70 & 260 & 0.39 & 160 \\
\hline 4 & 2.5 & 10 & 50 & 70 & $240^{b}$ & 0.41 & \\
\hline 5 & 1.75 & 6.5 & 55 & 89 & 260 & 0.51 & - \\
\hline 6 & 1.75 & 10 & 55 & 89 & 260 & 0.46 & 103 \\
\hline 7 & 2.0 & 10 & 50 & 82 & 260 & 0.44 & 135 \\
\hline
\end{tabular}

a Molar ratio of $\mathrm{SO}_{2}$ to $\mathrm{NaHCO}_{3}$ was fixed to 1.3 in order to keep pH of the polymerization system 3.0. $\mathrm{Fe}^{2+}$ was fed $0.4 \mathrm{ppm}$ by weight of monomer.

$b$ Bulk density of dry power.

c Filter cake after dewatering slurry at leaf test.

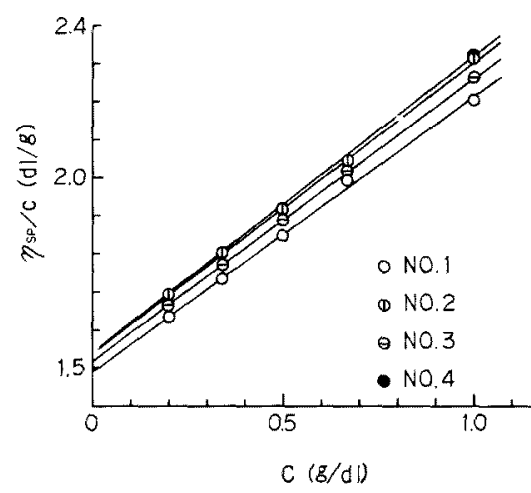

Fig. $1 \eta_{\mathrm{sp}} / C$ versus $C$ of polymer samples in $0.1 \mathrm{M}-\mathrm{NaSCN} / \mathrm{DMF}$ at $30^{\circ} \mathrm{C}: 0$, expt. No. $1, \oplus$, No. $2, \ominus$, No. $3, \bullet$, No. 4 in Table 1.

unusual curves owing to the strong acid groups of the polymers originated from initiators. This is considered to be due to the unusual expansion of polymer chains caused by electrostatic interactions of the strong acid groups. They also have shown that correct M.W.D. could be obtained by GPC measurement in such a solvent system as $0.1 \mathrm{M}$ $\mathrm{NaSCN} / \mathrm{DMF}$. Hence, in this study, GPC measurement was performed in $0.1 \mathrm{M} \mathrm{NaSCN} / \mathrm{DMF}$. Calibration curve is necessary to calculate M.W.D. and several kinds of average molecular weight. The universal calibration curve prepared from poly-

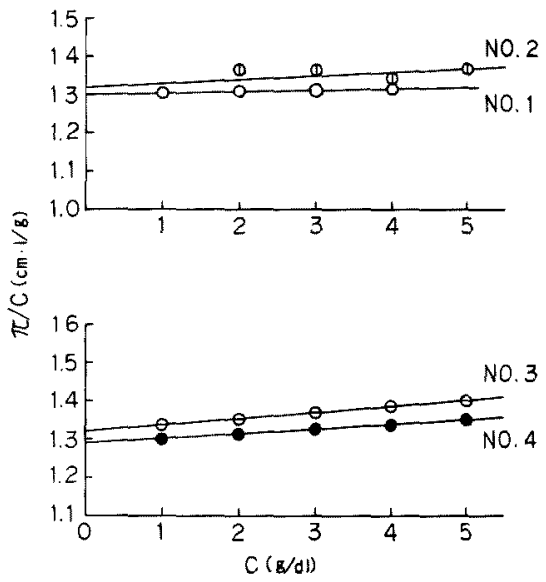

Fig. $2 \pi / C$ versus $C$ of polymer samples in DMF at $30^{\circ} \mathrm{C}: O$, expt. No. $1, \Phi$, No. $2, \theta$, No. 3, No. 4 in Table 1.

styrene is not applicable to PAN as previously stated ${ }^{6}$. Hence it is necessary to make new calibration curve with monodisperse polymers prepared from the polymer concerned in this study. To obtain such polymers the AN/VAc copolymers (AN/VAc 93/7 in weight) prepared under the condition corresponding to expt. No. 1 in Table 1, were fractionated by the precipitation fractionation. Details of fractionation method are described elsewhere ${ }^{9}$. Intrinsic viscosity, $\bar{M}_{\mathrm{n}}$ and 
Table 2 Molecular weight and related data of polymer samples

\begin{tabular}{|c|c|c|c|c|c|c|c|}
\hline $\begin{array}{c}\text { Sample } \\
\text { No. } \\
\end{array}$ & $\begin{array}{l}{[\eta]^{b}} \\
(\mathrm{~d} \mid / g) \\
\end{array}$ & $k^{\prime}$ & $\begin{array}{r}\bar{M}_{\mathrm{n}} \\
\times 10^{-4} \\
\end{array}$ & $\mathrm{Pn}^{\mathrm{c}}$ & $\begin{array}{c}A_{2} \times 10^{4} \\
(\mathrm{~mol} \cdot \mathrm{ml} / \mathrm{g}) \\
\end{array}$ & $\begin{array}{r}\bar{M}_{v}{ }^{d} \\
\times 10^{-4} \\
\end{array}$ & $\bar{M}_{\mathrm{v}} / \bar{M}_{\mathrm{n}}$ \\
\hline 1 & 1.49 & 0.324 & 2.09 & 378 & 2.51 & 11.9 & 5.69 \\
\hline 2 & 1.54 & 0.327 & 2.07 & 374 & 4.59 & 12.5 & 6.04 \\
\hline 3 & 1.52 & 0.320 & 2.05 & 371 & 5.71 & 12.3 & 6.00 \\
\hline 4 & 1.54 & 0.326 & 2.10 & 380 & 5.05 & 12.5 & 5.95 \\
\hline
\end{tabular}

a Sample No. 1 - No. 4 corresponds to Expt. No. 1 - No. 4 in Table 1.

b Obtained by extrapolation to $C=0$ in Fig. 1

c Number average degree of polymerization

d $[\eta]=7.486 \times 10^{-4} \bar{M}_{\mathrm{v}}{ }^{0.650}\left(0.1 \mathrm{M}-\mathrm{NaSCN} / \mathrm{DMF}, 30^{\circ} \mathrm{C}\right)$

Table 3 Intrinsic viscosity and molecular weight of fractions of the AN/VAc copolymer sample ${ }^{a}$

\begin{tabular}{|c|c|c|c|c|c|c|}
\hline Fr. No. & {$[\eta](\mathrm{d} 1 / \mathrm{g})^{\mathrm{b}}$} & {$[\eta](d l / g)^{c}$} & $\bar{M}_{\mathrm{n}} \times 10^{-4}$ & $\bar{M}_{\mathrm{v}}^{\mathrm{d}} \times 10^{-4}$ & $\begin{array}{c}\left(\bar{M}_{\mathrm{n}} \times \bar{M}_{\mathrm{y}}\right)^{1 / 2} \\
\times 10^{-4}\end{array}$ & $\bar{M}_{\mathrm{v}} / \bar{M}_{\mathrm{n}}$ \\
\hline 1 & 2.74 & 2.51 & 9.85 & 26.3 & 16.1 & 2.67 \\
\hline 2 & 2.30 & 2.16 & 12.0 & 22.3 & 16.4 & 1.86 \\
\hline 3 & 2.07 & 1.98 & 10.1 & 18.0 & 13.5 & 1.78 \\
\hline 4 & 1.73 & 1.71 & 6.42 & 14.0 & 9.48 & 2.18 \\
\hline 5 & 1.38 & 1.35 & 4.13 & 10.0 & 6.43 & 2.42 \\
\hline 6 & 0.850 & 0.847 & 2.80 & 5.10 & 3.05 & 1.82 \\
\hline
\end{tabular}

a Prepared under the conditions corresponding to Expt. No. 1 in Table 1.

b Measured in DMF at $30^{\circ} \mathrm{C}$

c Measured in $0.1 \mathrm{M} \mathrm{NaSCN} / \mathrm{DMF}$ at $30^{\circ} \mathrm{C}$

$\mathrm{d}[\eta]=4.57 \times 10^{-4} \mathrm{M}_{\mathrm{v}}^{0.70}$ (DMF, $30^{\circ} \mathrm{C}$, Senuma's equation)

related data of fractionated polymers are shown in Table 3.

$\bar{M}_{\mathrm{v}}$ was calculated from [ $\left.\eta\right]$ on 2 nd column by the eq. (3) obtained by A. Senuma et al. ${ }^{10)}$

$$
[\eta]=4.57 \times 10^{-4} M_{\mathrm{v}}^{0.70}\left(\mathrm{DMF}, 30^{\circ} \mathrm{C}\right)
$$

[ $\eta$ ] measured in $0.1 \mathrm{M} \mathrm{NaSCN} / \mathrm{DMF}$ was correlated to $\bar{M}_{\mathrm{v}}$ above evaluated, to obtain equation (4).

$$
\begin{aligned}
{[\eta]=} & 7.486 \times 10^{-4} M_{\mathrm{v}}^{0.650} \\
& \left(0.1 \mathrm{M} \mathrm{NaSCN} / \mathrm{DMF}, 30^{\circ} \mathrm{C}\right)
\end{aligned}
$$

The exponent of $M_{\mathrm{v}}$ of eq. (4) is smaller than that of eq. (3), so that $0.1 \mathrm{M} \mathrm{NaSCN} / \mathrm{DMF}$ is a poorer solvent than DMF for PAN.

From Table 3, $\bar{M}_{v} / \bar{M}_{\mathrm{n}}$ ratios of fractionated polymers are roughly 2 , so that these fractions are not monodisperse. Hence, it is not obvious what kind of average molecular weight corresponds to the peak of elition curve of GPC for the fractionated polymers. If M.W.D. of the samples conforms to Wesslau's distribution ${ }^{11)}$, it is shown that $\left(M_{\mathrm{w}} \times\right.$ $\left.M_{\mathrm{n}}\right)^{1 / 2}$ is the average molecular weight (MPGPC) corresponding to the peak of elution curve of GPC. In this study, $\left(M_{\mathrm{v}} \times M_{\mathrm{n}}\right)^{1 / 2}$ was used as MPGPC, $M_{\mathrm{w}}$ being replaced with $M_{\mathrm{v}}$.

Fig. 3 shows the correlation between MPGPC $x$

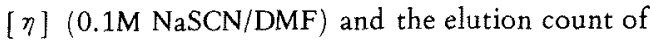
the peak of GPC. The same correlation curve for polystyrene are also shown in Fig. 3, though the former did not conform to the latter universal calibration curve. Eq. (5) was obtained as calibration curve for this polymer from the correlation 


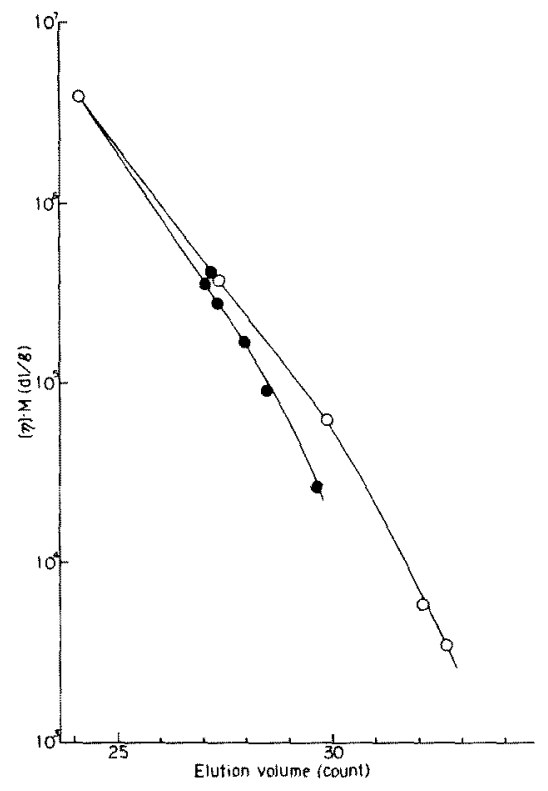

Fig. 3 Hydrodynamic volume versus elution volume for polystyrene and AN/VA copolymer in $0.1 \mathrm{M} \mathrm{NaSCN} / \mathrm{DMF}$ at $30^{\circ} \mathrm{C}$; $\bigcirc$, polystyrene $\left(M=M_{w}\right) ; \bullet$, AN/VA copolymer $\left(M=\left(M_{\mathrm{n}} \times M_{\mathrm{v}}\right)^{1 / 2}\right)$.

curve of Fig. 3.

$$
\begin{aligned}
Q= & {[\eta] \cdot M=7.486 \times 10^{-4} \cdot M^{1.650} } \\
= & 18.69-1.140 \mathrm{~V}+4.463 \times 10^{-2} \cdot V^{2} \\
& -7.558 \times 10^{-4} V^{3}
\end{aligned}
$$

$\bar{M}_{\mathrm{n}}, \bar{M}_{\mathrm{w}}, \bar{M}_{z}$ and M.W.D. can be calculated by eq. (5) from GPC curves. Fig. 4 shows GPC curves for No. $1-$ No. 4 samples. [ $\eta], \bar{M}_{\mathrm{n}}$, and $\bar{M}_{\mathrm{w}}$ were calculated by equation (5) from GPC curves shown in Fig. 4.

Calculated values of $\bar{M}_{\mathrm{n}}$ were larger than the observed ones. It is considered that it might be caused by the presence of impurities in low molecular weight region 7$)$. Although the calculated $\bar{M}_{\mathrm{w}} / \bar{M}_{\mathrm{n}}$ ratios were smaller than the observed values, no marked difference exists in M.W.D. of No. 1-No. 4 samples. Fig. 5 shows integral molecular weight distribution curves for No. 1 and No. 4 samples. No marked difference in M.W.D. was observed in the curve.

Curves of No. 4-No. 7 samples obtained by the high speed GPC are shown in Fig. 7. The results of high speed GPC measurements were analysed by calibration curve derived from fractionated

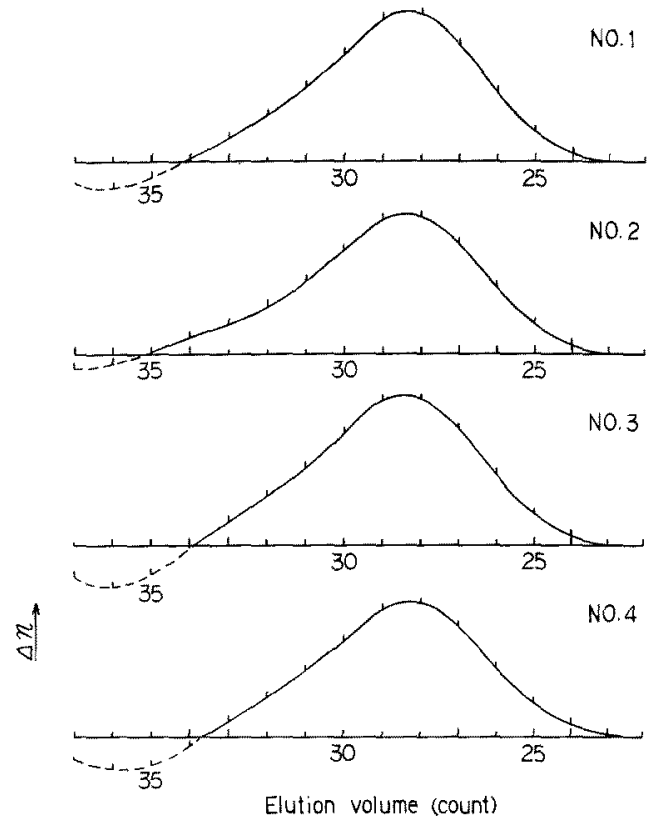

Fig. 4 GPC curves of the polymer prepared under the conditions of expt. No. 1 , No. 2 , No. 3 and No. 4 in Table 1.



Fig. 5 Integral molecular weight distribution curve: - No. $1 ; \ldots$, No. 4 in Table 1.

polymers in Fig. 6. The calculated values are listed in Table 5. This GPC system was inferior to the conventional type GPC in resolving power because the slope of the curve in Fig. 6 was larger than that of Fig. 3. Hence $\bar{M}_{\mathrm{n}}$ calculated for No. 4 sample in Table 5 was larger than that of Table 4.

Although $[\eta], \bar{M}_{\mathrm{n}}, \bar{M}_{\mathrm{w}}$ and $\bar{M}_{z}$ calculated for No. 5-No. 7 samples were larger than those listed in Table $4, \bar{M}_{\mathrm{w}} / \bar{M}_{\mathrm{n}}$ ratios were approximately 5 and comparable to those in Table 4. Based on these results, it is concluded that no marked change occurs in M.W.D. of polymers produced 


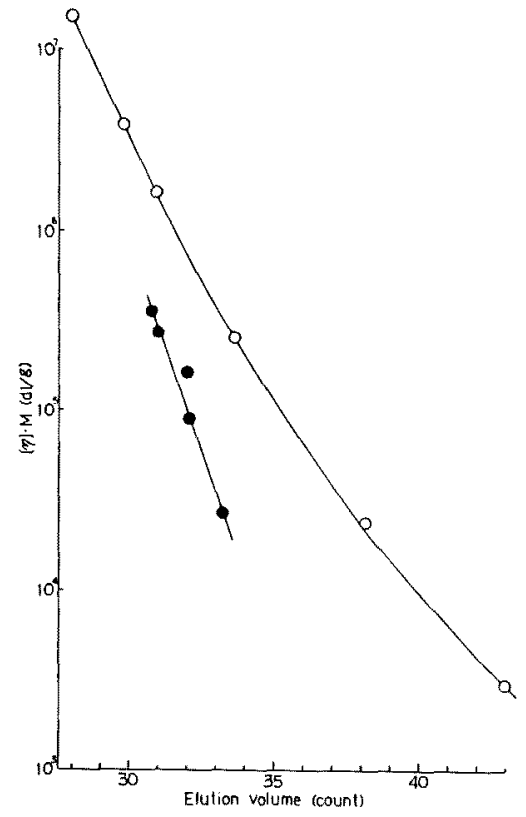

Fig. 6 Hydrodynamic volume versus elution volume for polystyrene and AN/VA copolymer in $0.1 \mathrm{M}-\mathrm{NaSCN} / \mathrm{DMF}$ at $30^{\circ} \mathrm{C}$ : $\bigcirc$, polystyrene $\left(M=M_{\mathrm{w}}\right) ; \bullet$, AN/VA copolymer $\left(M=\left(M_{\mathrm{n}} \times M_{\mathrm{v}}\right)^{1 / 2}\right)$.


Fig. 7 GPC curves of the polymer prepared under the conditions of expt. No. 5, No. 6 , No. 7 and No. 4 in Table 1: -...., No. 4.

Table 4 Molecular weight and related data calculated from GPC results

\begin{tabular}{|c|c|c|c|c|c|c|}
\hline Sample $^{a}$ No. & {$[\eta]^{\mathrm{b}}(\mathrm{dl} / \mathrm{g})$} & $\bar{M}_{\mathrm{n}}^{\mathrm{b}} \times 10^{-4}$ & $\bar{M}_{\mathrm{w}}^{\mathrm{b}} \times 10^{-4}$ & $\bar{M}_{z}^{\mathrm{b}} \times 10^{-4}$ & $\underline{\bar{M}}_{\mathrm{w}} / \bar{M}_{\mathrm{n}}$ & $\underline{\bar{M}_{2} / \bar{M}_{\mathrm{w}}}$ \\
\hline 1 & 1.43 & 2.64 & 13.6 & 32.2 & 5.16 & 2.36 \\
\hline 2 & 1.38 & 1.65 & 13.0 & 30.1 & 7.86 & 2.33 \\
\hline 3 & 1.42 & 2.80 & 13.0 & 28.8 & 4.65 & 2.21 \\
\hline 4 & 1.51 & 3.34 & 14.6 & 33.2 & 4.36 & 2.28 \\
\hline
\end{tabular}

a Sample No. 1 - No. 4 corresponds to Expt. No. 1 - No. 4 in Table 1 .

b Calculated by following eqs. (6) - (9), from Figs. 3 and 4 .

$$
\begin{aligned}
& {[\eta]=\mathrm{K}^{\frac{1}{a+1}} \sum \mathrm{WiQ}^{\frac{\mathrm{a}}{\mathrm{a}+1}}} \\
& \bar{M}_{\mathrm{n}}=\frac{\mathrm{K}^{-\frac{1}{\mathrm{a}+1}}}{\sum \mathrm{WiQ}_{\mathrm{Q}} \mathrm{i}^{-\frac{1}{\mathrm{a}+1}}} \\
& \bar{M}_{\mathrm{W}}=\mathrm{K}^{-\frac{1}{\mathrm{a}+1}} \sum \mathrm{WiQj}^{\frac{1}{\mathrm{a}+1}} \\
& \bar{M}_{z}=\mathrm{K}^{-\frac{1}{3+1}} \frac{\sum \mathrm{WiQj}^{\frac{2}{\mathrm{j}^{3}+1}}}{\sum \mathrm{WiQ}^{\frac{1}{a+1}}}
\end{aligned}
$$$$
\text { (6) where } K \text { and a are defined in eq. (10). }
$$

$$
[\eta]=\mathrm{KM}^{\mathrm{a}}
$$
here, eq. (10) corresponds to eq. $(4) ; \mathrm{K}=7,486 \times 10^{-4}$

(8) $\quad a=0.650$ 
Table 5 Molecular weight and related data of polymers prepared under the condition of Table 1 calculated from GPC results

\begin{tabular}{|c|c|c|c|c|c|}
\hline Sample ${ }^{a}$ No, & $\mathrm{Nsp}^{\mathrm{b}}$ & {$[\eta]^{c}$} & $\bar{M}_{\mathrm{n}} \times 10^{-4} \mathrm{c}$ & $\bar{M}_{\mathrm{w}} \times 10^{-4} \mathrm{c}$ & $\bar{M}_{\mathrm{w}} / \bar{M}_{\mathrm{n}}$ \\
\hline 5 & 0.204 & 2.10 & 5.64 & 28.4 & 5.04 \\
\hline 6 & 0.203 & 1.97 & 5.42 & 25.2 & 4.64 \\
\hline 7 & 0.189 & 2.08 & 5.45 & 27.9 & 5.11 \\
\hline 4 & 0.205 & 1.49 & 3.73 & 16.5 & 4.43 \\
\hline
\end{tabular}

a Sample No. 4 - No. 7 corresponds to Expt. No. 4 - No. 7 in Table 1

b Nsp denotes reduced viscosity $\left(0.5 \%\right.$ polymer in $25^{\circ} \mathrm{C}$ DMF $) \times 0.1$

c Calculated by the same method as mentioned in Table 4 .

under the conditions of water/monomer ratio varied from 4.0 to 1.75 in this polymerization system. $\bar{M}_{\mathrm{w}} / \bar{M}_{\mathrm{n}}$ and $\bar{M}_{\mathrm{v}} / \bar{M}_{\mathrm{n}}$ ratios are apparently larger than the reported values ${ }^{12), 13)}$. Mixing ${ }^{14), 15)}$, heterogeneity ${ }^{16-19)}$ in polymerization systems, and the polymer composition (PAN and AN-VAc copolymer) are considered to cause the difference in $\bar{M}_{\mathrm{w}} / \bar{M}_{\mathrm{n}}$ ratios to some extent.

Although the marked change in polymer particles occurred in this system with the range of water/ monomer ratio from 4,0 to 1.75 as described above partly and in the previous paper ${ }^{5)}$, no marked change was observed in M.W.D. of the polymers prepared with this particular range of water/monomer ratio. The result described above is industrially valuable. First, we can choose any level of water to monomer ratio in the range from 1.75 to 4.0 without significant change in polymer qualities connected with those of shaped articles therefrom. In this polymerization system M.W.D. affects strong acid end groups of polymer which directly correlates dyeability of shaped articles ${ }^{13}$ ). M.W.D. affects the mechanical properties of shaped articles such as fibers, too. ${ }^{20}$ ), 21) Hence in this range, we can choose the best condition, taking into consideration the factors including dewatering property, bulk density of polymer, conversion rate, $\mathrm{KPS} /$ monomer ratio, and agitation power from cost and stability of the process. Secondly, we can produce polymer of normal quality shortly after the start of polymerization without uneconomical production of off grade polymer in large quantity at the start of polymerization.

The results described above show suggestions concerning the mechanism of the polymerization in this system, too. Effect of water to monomer ratio on M.W.D. had not been known before this study. With decreasing water to monomer ratio, the polymer content in the polymerization system increases and consequently the surface area of polymer particles attacked by radicals in the aqueous phase per unit volume of the aqueous phase increases. ${ }^{22)}$ Hence, it is supposed ${ }^{22)}$ that polymerization in the polymer phase would increase to produce comparatively high molecular weight polymer, which would enlarge M.W.D. to some degree. However, the results obtained in this paper show that this effect was not distinctive. No marked difference in M.W.D. from GPC suggests that the mechanism of the polymerization in this system does not change largely in the range of water to monomer ratio from 4 to 1.75 . It approximately corresponds to the results of a kinetic study concerning this polymerization system. ${ }^{23)}$

\section{ACKNOWLEDGEMENT}

We wish to thank the Mitsubishi Rayon Co., Ltd. for the permission to publish this paper.

\section{REFERENCES}

1) W. M. Thomas and W. C. Mallison, Petroleum Refiner, 40, No. 5. 211 (1961).

2) W. C. Mallison, (American Cyanamid), U.S. Pat. 2,777,832 (1957) and 2,847,405 (1958).

3) Charles Clifford Ketter, (E. I. du Pont), U.S. Pat. 2,974,123 (1961).

4) Myron Q. Webb and Williamson, (E. I. du Pont), U.S. Pat. 2,992,209 (1961).

5) S. Ito and K. Yoshida, Kobunshi Ronbunshu, 40, 307 (1983). 
6) T. Masuzawa, K. Kamada and T. Yoshihara, Reports on Progress in Polymer Physics in Japan, Vol. XVI, 127 (1973).

7) T. Masuzawa, K. Kamada and T. Yoshihara, Reports on Progress in Polymer Physics in Japan, Vol. XVII, 75 (1974).

8) T. Masuzawa, K. Kamada and T. Yoshihara, Reports on Progress in Polymer Physics in Japan, Vol. XVIII, 19 (1975).

9) Paper contributed to J. Appl. Polym. Sci., by $\mathrm{S}$. Ito, C. Okada and $\mathrm{K}$. Kamada entitled "Distributions of End Groups and Comonomer of the Acrylonitrile-Viny Acetate Copolymer from Redox Polymerization" (in press).

10) A. Senuma, H. Sato and N. Yamada, 15th Symposium of High Polymer (Japan). Nov. 19, 1966, Abstracts of Papers.

11) H. Wesslau, Markromol. Chem., 20, 111 (1956).

12) L. H. Peebles, Jr., P. B. Thompson, Jr., J. R. Kirby, and M. E. Gibson, J. Appl. Polym.
Scio, 16, 3341 (1972).

13) L. H. Peebles, Jr., J. Appl. Polym. Sci., 17, 113 (1973).

14) K. G. Denbigh, Trans. Faraday Soc., 43, 648 (1947).

15) M. Harada, W. Eguchi, S. Nagata, Chem. Eng. (Japan), 26, 583 (1962).

16) W. M. Thomas, Fortschr. Hochpoly. Forsch., 2, 401 (1961).

17) H. Shirouchi, S. Yuguchi and M. Watanabe, Kogyo Kagaku Zasshi, 67, 1063 (1964).

18) C. H. Bamford and A. D. Jenkins, Proc. Roy. Soc., Ser. A 216 (1953) S. 515.

19) G. R. Cotten, W. C. Schneider, J. Appl. Polym. Sci. 7, 1243 (1963).

20) Y. Fujisaki, Kobunshi Kagaku, 18, 667 (1961).

21) M. Takahashi, Kogyo Kagaku Zasshi, 65, 114 (1962)

22) S. Ito, a paper in preparation.

23) S. Ito, Kobunshi Ronbunshu, 42, 865 (1985).

レドックス重合により得られたアクリロニトリルー

酢酸どニル共重合体の分子量分布*

三萲レイヨン株式会社 伊藤精一, 岡田千春 ${ }^{* *}$

アクリロニトリル/酷酸ビ二ル共重合体 $(93 / 7$ 重量比) を $\mathrm{SO}_{2} /$ 過硫酸カリウム系レドックス開始剤を用い水系 连続重合汇より製造するに当り，重合条件として水/モ /マー比孝 4.0 (重量比)より 1.75 の範国で小さくしてい くと，得られたポリマー粒子はち密になり，加さ密度は 大きく，生成スラリーのポリマー保水性は小さくなるこ

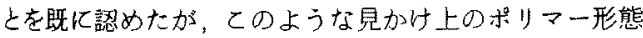

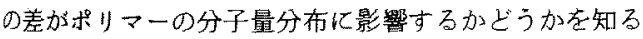
ため水/モ/マー此を 4.0 より 1.75 まで変えて得られた ポリマーの分子量分布を評価した。分子量分布は粘度及
び浸透正測定より求めた $\bar{M}_{\mathrm{v}} / \bar{M}_{\mathrm{n}}$ 比並びに既検討の塩を 添加した DMF 溶媒を用いるGPC上り求めた $\vec{M}_{\mathrm{w}} / \bar{M}_{\mathrm{n}}$ 比任上り評価した。尗、ーの分子量分布は底く $\bar{M}_{\mathrm{w}} /$ $\bar{M}_{\mathrm{n}}$ 比は 4 60間で変動しているが、水/モノマー比の 影響による顕著な差は認模いものであった。

*乙の報文を「低水/モノマー比化拈るアクリロニ トリル水䒺連続重合の研究(第7 報)」とする。

***現在の所属：花王 (怢)和歌山研究所, 和歌山市港 1334 